\title{
Point-of-Care Ultrasound as a Diagnostic Tool for Nutcracker Syndrome in Pediatric Emergency Department
}

\author{
Çocuk Acil Serviste Nutcracker Sendromu için Yol Gösterici Tanısal Araç Olarak Hasta Başı \\ Ultrasonografi
}

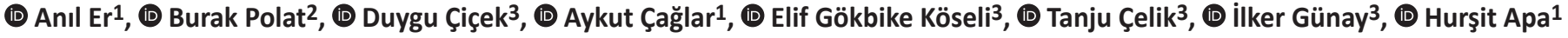

1 University of Health Sciences, Dr. Behçet Uz Child Disease and Pediatric Surgery Training and Research Hospital, Clinic of Pediatric Emergency, Izmir, Turkey 2 University of Health Sciences, Dr. Behçet Uz Child Disease and Pediatric Surgery Training and Research Hospital, Clinic of Radiology, Izmir, Turkey 3 University of Health Sciences, Dr. Behçet Uz Child Disease and Pediatric Surgery Training and Research Hospital, Clinic of Pediatrics, izmir, Turkey
\end{abstract}

\section{Abstract}

Abdominal pain is one of the most common causes of admission to pediatric emergency department. Point-of care ultrasonography combined with appropriate history and physical examination provides rapid and accurate management of abdominal pain in emergency setting. Here, we report a 15-year-old girl with abdominal pain who was diagnosed with Nutcracker syndrome by the guidance of pointof-care ultrasound findings.

Keywords: Point-of-care ultrasound, renal vein, Nutcracker syndrome, child

\section{Introduction}

Nutcracker syndrome (NCS) is defined as complex clinical symptoms related with left renal vein (LRV) compression. ${ }^{1-4}$ As the symptoms are non-specific and it is difficult to diagnose NCS, the actual prevalence is unknown. ${ }^{3}$ It usually presents with hematuria, abdominal pain, orthostatic proteinuria, varicocele, dyspareunia, dysmenorrhea. ${ }^{2-4}$

The diagnosis can be established based on clinical suspicion supported by radiological findings as the symptoms and signs of NCS are non-specific. It is essential to demonstrate the anatomical and pathophysiological features of NCS by ultrasound (US).-8 Here, we report a 15-year-old girl who presented with recurrent abdominal pain and was diagnosed with NCS by the guidance of point-of-care US (POCUS) in the emergency department.

\section{Öz}

Karın ağrısı çocuk acil servise en sık başvuru nedenlerinden biridir. Acil koşullarında uygun öykü ve fizik muayene ile birleştirilmiş hasta başı ultrasonografi karın ağrısına hızlı ve doğru şekilde yaklaşıımasını sağlar. Burada karın ağrısı olan ve hasta başı ultrasonografi bulguları ile Nutcracker sendromu tanısı alan 15 yaşında kız hasta bildirilmiştir. Anahtar Kelimeler: Hasta başı ultrasonografi, renal ven, Nutcracker sendromu, çocuk

\section{Case}

A 15-year-old girl was admitted to the pediatric emergency department with abdominal pain and bloating. She had multiple hospital admissions due to these complaints in the past 2 months. The pain was perceived at the left lower quadrant and spread to the left flank. She noticed that the pain was triggered by physical activity. She denied fever, vomiting, constipation, diarrhea, dyspepsia, dysuria, urine color changes and history of trauma. Abdominal pain was accompanied by anorexia and menstrual cycle irregularity. The vital signs were normal for her age. Physical examination revealed left costovertebral angle and mild left lower quadrant tenderness without guarding or rebound.

The levels of liver enzymes, creatinine and serum electrolytes were within the normal range. C-reactive protein was unremarkable and white blood cell count was $8.390 / \mu \mathrm{L}$. 
The hemoglobin level was $14 \mathrm{~g} / \mathrm{dL}$ and platelet count was $213.000 / \mu \mathrm{L}$. There was no hematuria or proteinuria in urine analysis. A pediatric emergency medicine physician performed POCUS for suspected renal or pelvic disorder. There was no hydronephrosis, urolithiasis or free fluid in the pouch of Douglas. However, we observed an enlarged LRV with a diameter of $9.4 \mathrm{~mm}$ at the aortomesenteric junction and $1.8 \mathrm{~mm}$ at branching (Figure 1). Under the guidance of POCUS findings, Doppler US was performed by a radiologist for confirming the diagnosis of NCS. The narrowed aortomesenteric angle (AMA) was measured as $23^{\circ}$ (Figure 2 ). Peak velocity (PV) was measured as $27 \mathrm{~cm} / \mathrm{s}$ at the distended portion and $120 \mathrm{~cm} / \mathrm{s}$ at the narrowed portion of the LRV. The measurements were repeated in the standing position; revealing $36 \mathrm{~cm} / \mathrm{s}$ and $197 \mathrm{~cm} / \mathrm{s}$ respectively. PV ratio was 4.4 in the supine position and 5.5 in the upright position. The diameter of the ovarian veins was normal.

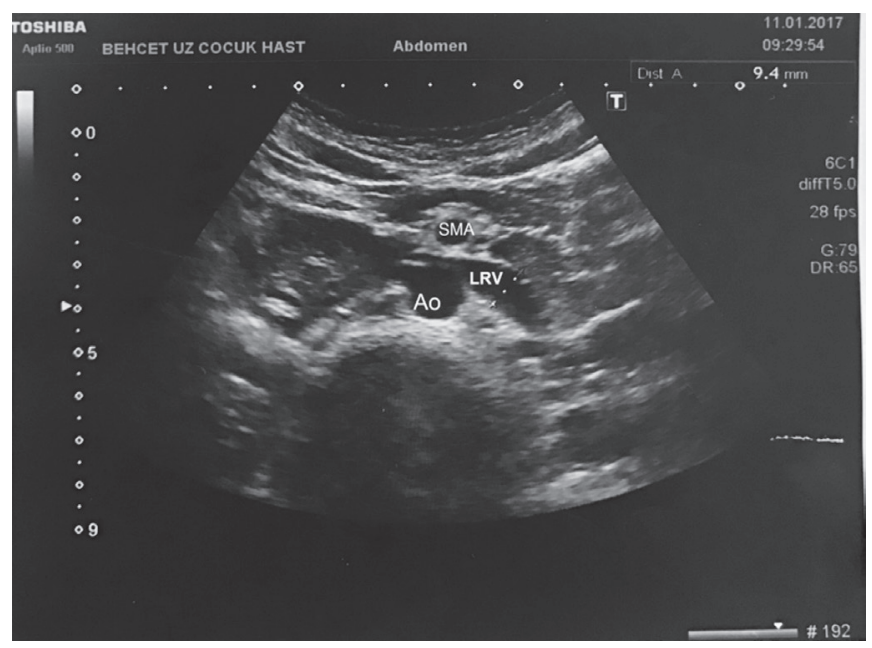

Figure 1. Point-of care ultrasound demonstrated theenlarged left renal vein LRV: Left renal vein, Ao: Aorta, SMA: Superior mesenteric artery

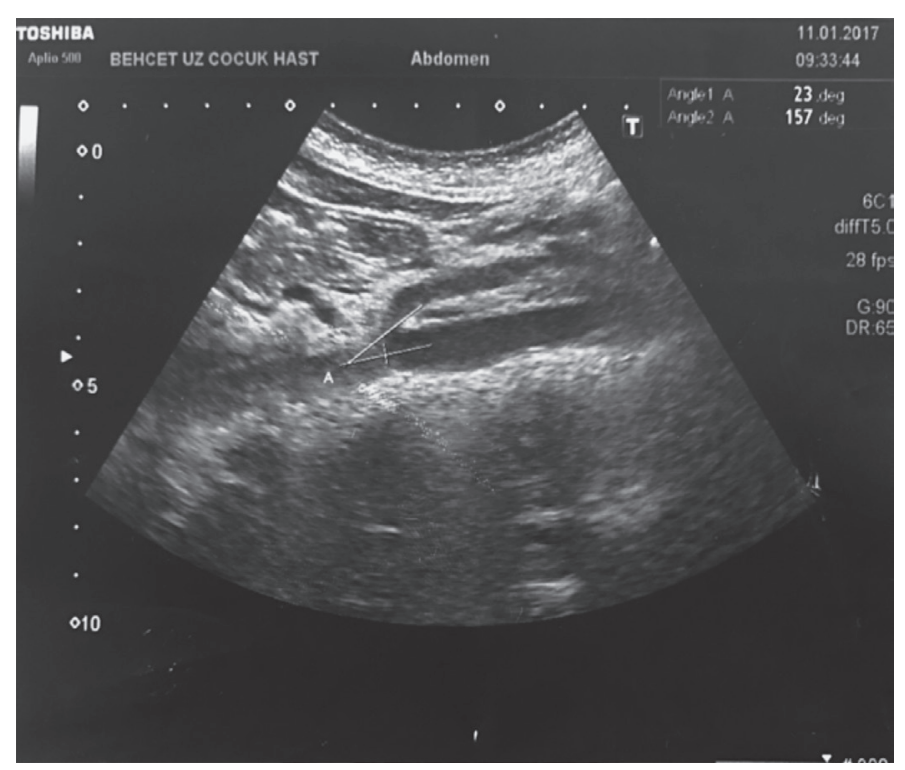

Figure 2. Point-of care ultrasound image of narrowed aortomesenteric angle

\section{Discussion}

POCUS is used as a non-invasive tool for rapid assessment of abdominal pain in emergency setting. ${ }^{9,10}$ Physicians should consider that it is a rule in technique and the most important part of an effective POCUS is to focus on the prediagnosis obtained from history and physical examination. ${ }^{11}$ We performed POCUS with the pre-diagnosis of renal or pelvic disorder in a 15-year-old girl with recurrent abdominal pain, anorexia and menstrual cycle irregularity. However, we unexpectedly realized an enlarged LRV compared with the right renal vein and the patient was diagnosed as having NCS by Doppler US performed on account of the findings of POCUS.

NCS is characterized by complex clinical symptoms related with compression of the LRV. ${ }^{1-4}$ It is also defined as "LRV entrapment syndrome" based on anatomical and physiologic features. The typical characteristic is anterior nutcracker which involves compression of the LRV by the forking of the aorta and superior mesenteric artery. Rarely, the retroaortic or circumaortic LRV is located between the vertebrae and aorta which is termed posterior nutcracker. ${ }^{2-4}$

LRV hypertension-related clinical symptoms are diverse and non-specific. $2,3,6,12$ However, exacerbation by the long period of standing and walking is remarkable. ${ }^{3,4,13}$ In retrospect our patient also had recurrent admissions with abdominal pain triggered by physical activity. The most common manifestations of NCS are hematuria and abdominal pain..$^{2,3}$ Collateral varices bleeding through adjacent renal calyces leads to hematuria. It can be presented by asymptomatic microscopic hematuria also macroscopic hematuria with consequent anemia. ${ }^{3,4,14}$ Additionally, the blood clots moving through ureter can result in colicky left flank and abdominal pain. ${ }^{3}$ The other reason for abdominal pain is gonadal vein syndrome related with pelvic venous congestion. It is the most serious manifestation of NCS presenting with dyspareunia, dysmenorrhea, dysuria in females; varicocele in males. $2,3,15,16$

The diagnosis of NCS depends on clinical suspicion and demonstration of the anatomic features by the imaging techniques. Recently, diagnostic tools, such as renal angiography, magnetic resonance imaging, magnetic resonance angiography and venography, have been replaced by US which is a rapid, reliable and non-invasive method. $3,4,17,18$ On the other hand, effective interpretation of US measurements can be obtained by the knowledge of normal ranges. The AMA ranges between $25^{\circ}$ and $100^{\circ}$ in adults, but there is limited data in children. ${ }^{1}$ Thus, the accurate scanning should include measurement of diameter and PV of LRV at the aortomesenteric and hilar portions and also collateral flow by Doppler US. $23,6-8,19,20$ The cutoff value for diameter ratio ranges from 4.0 to 5.0 and PV ratio ranges 
from 4.1 to 5.0 in the literature. ${ }^{5-7,19,20}$ The AMA in our patient was not significantly narrow with $23^{\circ}$, but the PV ratio was 4.4 comparable with NCS.

The management of NCS depends on the severity of symptoms and US findings. Conservative approach can be preferred for mild symptoms in that spontaneous resolution by weight gain has been reported. 2,13 On the other hand, patients with severe and/or persistent symptoms should be treated by endovascular or surgical approaches. ${ }^{2-4,21,22}$ Thus, we preferred to approach conservatively for our patient with mild symptoms.

In conclusion NCS is a rare and challenging cause of abdominal pain due to its non-specific clinical features and the lack of diagnostic criteria in children. We suggest that realizing the enlarged LRV by POCUS can provide a rapid diagnosis of NCS in the high suspicion of pediatric emergency physicians.

\section{Ethics}

Informed Consent: The written informed consent of patients father was taken.

Peer-review: Internally peer-reviewed.

\section{Authorship Contributions}

Surgical and Medical Practices: D.Ç., B.P., Concept: E.G.K., Design: T.Ç., Data Collection or Processing: H.A., Analysis or Interpretation: A.Ç., Literature Search: A.E., I.G., Writing: A.E.

Conflict of Interest: No conflict of interest was declared by the authors.

Financial Disclosure: The authors declared that this study received no financial support.

\section{References}

1. Arthurs OJ, Mehta U, Set PA. Nutcracker and SMA syndromes: What is the normal SMA angle in children? Eur J Radiol. 2012;81:e85461.

2. Alaygut D, Bayram M, Soylu A, Cakmakcı H, Türkmen M, Kavukcu S. Clinical course of children with nutcracker syndrome. Urology. 2013:82:686-90.

3. Kurklinsky AK, Rooke TW. Nutcracker phenomenon and nutcracker syndrome. Mayo Clin Proc. 2010;85:552-9.

4. Venkatachalam S, Bumpus K, Kapadia SR, Gray B, Lyden S, Shishehbor $\mathrm{MH}$. The nutcracker syndrome. Ann Vasc Surg. 2011;25:1154-64

5. Fitoz S, Ekim M, Ozcakar ZB, Elhan AH, Yalcinkaya F. Nutcracker syndrome in children: the role of upright position examination and superior mesenteric artery angle measurement in the diagnosis. J Ultrasound Med. 2007;26:573-80.
6. Shin JI, Park JM, Lee JS, Kim MJ. Doppler ultrasonographic indices in diagnosing nutcracker syndrome in children. Pediatr Nephrol. 2007;22:409-13.

7. Shin JI, Park JM, Lee JS, Kim MJ. Effect of renal Doppler ultrasound on the detection of nutcracker syndrome in children with hematuria. Eur J Pediatr. 2007;166:399-404.

8. Park SJ, Lim JW, Cho BS, Yoon TY, Oh JH. Nutcracker syndrome in children with orthostatic proteinuria: diagnosis on the basis of Doppler sonography. J Ultrasound Med. 2002;21:39-45.

9. Hasani SA, Fathi M, Daadpey M, Zare MA, Tavakoli N, Abbasi S. Accuracy of bedside emergency physician performed ultrasound in diagnosing different causes of acute abdominal pain: a prospective study. Clin Imaging. 2015;39:476-9.

10. O'Brien AJ, Brady RM. Point-of-care ultrasound in paediatric emergency medicine. J Paediatr Child Health. 2016;52:174-80.

11. Marin JR, Lewiss RE; American Academy of Pediatrics, Committee on Pediatric Emergency Medicine; Society for Academic Emergency Medicine, Academy of Emergency Ultrasound; American College of Emergency Physicians, Pediatric Emergency Medicine Committee; World Interactive Network Focused on Critical Ultrasound. Point-ofcare ultrasonography by pediatric emergency medicine physicians. Pediatrics. 2015;135:e1113-22.

12. Yavuz S, Kıyak A, Er A, Korkmaz O. The utility of bioimpedance analysis for monitoring the children with nutcracker syndrome. Eur J Pediatr. 2015;174:1393-7.

13. Shin JI, Park JM, Lee SM, Shin YH, Kim JH, et al. Factors affecting spontaneous resolution of hematuria in childhood nutcracker syndrome. Pediatr Nephrol. 2005;20:609-13.

14. Kavukcu S, Kasap B, Göktay Y, Seçil M. Doppler sonographic indices in diagnosing the nutcracker phenomenon in a hematuric adolescent. J Clin Ultrasound. 2004;32:37-41.

15. Rogers A, Beech A, Braithwaite B. Transperitoneal laparoscopic left gonadal vein ligation can be the right treatment option for pelvic congestion symptoms secondary to nutcracker syndrome. Vascular. 2007:15:238-40

16. Scultetus $A H$, Villavicencio JL, Gillespie DL. The nutcracker syndrome: its role in the pelvic venous disorders. J Vasc Surg. 2001;34:812-9.

17. Kaneko K, Kiya K, Nishimura K, Shimizu T, Yamashiro Y. Nutcracker phenomenon demonstrated by three-dimensional computed tomography. Pediatr Nephrol. 2001;16:745-7.

18. Kawamoto S, Horton KM, Fishman EK. Nutcracker phenomenon demonstrated by multidetector computed tomography with threedimensional imaging. Urology. 2008;71:228-9.

19. Cheon JE, Kim WS, Kim IO, Kim SH, Yeon KM, et al. Nutcracker syndrome in children with gross haematuria: Doppler sonographic evaluation of the left renal vein. Pediatr Radiol. 2006;36:682-6.

20. Kim SH, Cho SW, Kim HD, Chung JW, Park JH, Han MC. Nutcracker syndrome: diagnosis with Doppler US. Radiology. 1996;198:93-7.

21. Chen W, Chu J, Yang JY, Li HP, Zhuang WQ, et al. Endovascular stent placement for the treatment of nutcracker phenomenon in three pediatric patients. J Vasc Interv Radiol. 2005;16:1529-33.

22. Ullery BW, Itoga NK, Mell MW. Transposition of the left renal vein for the treatment of nutcracker syndrome in children: a short-term experience. Ann Vasc Surg. 2014;28:1938.e5-8. 